\title{
Neurturin-Mediated Ret Activation Is Required for Retinal Function
}

\author{
Milam A. Brantley Jr, ${ }^{1}$ Sanjay Jain, ${ }^{2,3}$ Emily E. Barr, ${ }^{1}$ Eugene M. Johnson Jr, ${ }^{3,4,5}$ and Jeffrey Milbrandt ${ }^{3,5,6}$ \\ ${ }^{1}$ Department of Ophthalmology and Visual Sciences, ${ }^{2}$ Department of Medicine, Renal Division, ${ }^{3}$ Hope Center for Neurological Disorders, and Departments \\ of ${ }^{4}$ Molecular Biology and Pharmacology, ${ }^{5}$ Neurology, and ${ }^{6}$ Pathology, Washington University School of Medicine, St. Louis, Missouri 63110
}

The glial cell line-derived neurotrophic factor (GDNF) family ligands (GFLs) [GDNF, NRTN (neurturin), ARTN (artemin), and PSPN (persephin)] interact with GDNF family receptors (GFR $\alpha$ s) and activate intracellular signaling through the Ret receptor tyrosine kinase. To characterize the role of Ret signaling in retinal activity, we examined Ret hypomorphic and Ret conditional mice using electroretinography. We found that aberrant Ret function resulted in markedly diminished scotopic and photopic responses. Using mice deficient in individual GFLs, we found that only NRTN deficiency led to reduced retinal activity. To determine the potential target cell type for NRTN, we examined the retinal expression of its coreceptors (GFR $\alpha 1$ and GFR $\alpha 2$ ) and Ret using mice expressing fluorescence reporter enhanced green fluorescent protein from their respective loci. We found robust GFR $\alpha 1$ and Ret expression in horizontal, amacrine, and ganglion cells, whereas GFR $\alpha 2$ expression was only detected in a subset of amacrine and ganglion cells. In contrast to previous studies, no expression of GFR $\alpha 1$, GFR $\alpha 2$, or Ret was detected in photoreceptors or Müller cells, suggesting that these cells are not directly affected by Ret. Finally, detailed morphologic analyses of retinas from NRTN- and Ret-deficient mice demonstrated a reduction in normal horizontal cell dendrites and axons, abnormal extensions of horizontal cell and bipolar cell processes into the outer nuclear layer, and mislocalized synaptic complexes. These anatomic abnormalities indicate a possible basis for the abnormal retinal activity in the Ret and NRTN mutant mice.

Key words: RET; neurturin; retina; ERG; horizontal; outer plexiform layer

\section{Introduction}

The glial cell line-derived neurotrophic factor (GDNF) family ligands (GFLs) [GDNF, NRTN (neurturin), ARTN (artemin), and PSPN (persephin)] form a complex with their respective GDNF family coreceptors (GFR $\alpha 1-$ GFR $\alpha 4$ ) and the receptor tyrosine kinase Ret to activate essential intracellular signaling cascades; these include the mitogen-activated protein kinase, phosphoinositide 3-kinase-AKT, and phospholipase $\mathrm{C} \gamma$ pathways (Baloh et al., 2000). Studies of mutant mice demonstrated that GFL-mediated RET signaling plays critical roles in organogenesis and in the maintenance of multiple central and peripheral neurons (Sariola and Saarma, 2003). In addition, GFLs show promise

Received Jan. 18, 2008; revised Feb. 24, 2008; accepted March 4, 2008.

This work was supported by National Institutes of Health (NIH) Neuroscience Blueprint Core Grant P30 NS057105 (Washington University), National Eye Institute (NEI) Core Grant P30 EY02687 and Research to Prevent Blindness (Washington University Department of Ophthalmology and Visual Sciences), the Carl Marshall Reeves and Mildred Almen Reeves Foundation and the McDonnell Center (M.B.), O'Brien Center for Kidney Disease Research Grant P30 DK079333, the HOPE Center for Neurological Disorders, NEI Grant EY016140 (M.B.), and NIH Grants AG013730 (J.M.), NSO39358 (J.M.), and HD047396 (S.J.).

J.M., E.M.J., and Washington University have a financial interest in Ceregene. Ceregene did not support this work. We thank Amy Strickland, Amanda Knoten, Nina Panchenko, Michael Dieckhaus, and Aaron Lee for technical assistance.

Correspondence should be addressed to either of the following: Dr. Milam A. Brantley Jr, Department of Ophthalmology and Visual Sciences, Campus Box 8096, Washington University School of Medicine, 660 South Euclid Avenue, St. Louis, M0 63110, E-mail: brantley@vision.wustl.edu; or Dr. Jeffrey Milbrandt, Department of Pathology, Campus Box 8118, Washington University School of Medicine, 660 South Euclid Avenue, St. Louis, M0 63110, E-mail: jmilbrandt@wustl.edu.

DOI:10.1523/JNEUROSCI.0249-08.2008

Copyright $\odot 2008$ Society for Neuroscience $\quad$ 0270-6474/08/284123-13\$15.00/0 for the treatment of several neurodegenerative diseases as well as neuropathic pain (McBride and Kordower, 2002; Kirik et al., 2004; Eslamboli, 2005; Sah et al., 2005). Finally, GDNF administration slows photoreceptor cell death in animal models of retinal degeneration (Carwile et al., 1998; Frasson et al., 1999; Ogilvie et al., 2000; McGee Saftner et al., 2001; Politi et al., 2001; AndrieuSoler et al., 2005; Delyfer et al., 2005), implying that GFLmediated RET signaling can influence retinal function.

To further understand the roles of GFLs and their receptors in the retina, a number of expression studies have been performed (Jomary et al., 1999; Harada et al., 2002; Karlsson et al., 2002; Koberle and Ball, 2002; Jomary et al., 2004; Rothermel et al., 2004; Kretz et al., 2006). However, because of discrepancies reported in expression patterns of these receptors, it has been difficult to predict their roles in retinal function. Although mutant mice deficient in each of the GFLs, their cognate GFR $\alpha$ coreceptors, and Ret exist, their roles in retinal function have not been examined because of perinatal lethality of some of the mutants. To this end, we examined the physiological roles of GFL-mediated Ret signaling and found that NRTN-mediated Ret signaling is required for normal retinal function. Using mice that express the enhanced green fluorescent protein (EGFP) reporter from the GFR $\alpha 1$, GFR $\alpha 2$, or Ret locus, we determined that Ret signaling in the retina likely occurs via horizontal, amacrine, or ganglion cells and not in Müller glial cells or photoreceptors. We further demonstrated that abnormal retinal activity in NRTN- or Retdeficient mice is associated with abnormal extension of horizon- 
tal cell and bipolar cell processes into the outer nuclear layer (ONL) as well as a severely disrupted outer plexiform layer (OPL), with very sparse horizontal cell dendrites and axons. We also observed mislocalized synaptic complexes in the outer nuclear layer in these mice. These studies show that NRTNmediated Ret signaling is critical to normal retinal development and function.

\section{Materials and Methods}

Mice. All studies were conducted in accordance with the Association for Research in Vision and Ophthalmology Statement for the Use of Animals in Ophthalmic and Vision Research. Institution-approved protocols were followed for all animal studies. Production and genotypic analysis of $\operatorname{Ret}^{\mathrm{DN} /+}, \mathrm{GDNF}^{+/-}, \mathrm{NRTN}^{-/-}, \mathrm{ARTN}^{-/-}$, and $\mathrm{PSPN}^{-1-}$ mice have all been described previously (Heuckeroth et al., 1999; Honma et al., 2002; Jain et al., 2004). Mice harboring the conditional RETfloxEGFP allele were bred with $\beta$-actinCre mice (Meyers et al., 1998) to generate mice expressing EGFP from the endogenous Ret locus (Jain et al., 2006b) and with Six3Cre mice (Furuta et al., 2000) to express EGFP from the Ret locus in the retina. Similarly GFR $\alpha 1$ conditional animals (Uesaka et al., 2007) were bred with $\beta$-actinCre mice (Meyers et al., 1998) to express EGFP reporter from the Gfr 1 locus. Mice expressing EGFP from the Gfr 22 locus have been described previously (McDonagh et al., 2007).

Electrophysiology. Full-field electroretinograms (ERGs) were recorded on a UTAS-E 3000 Visual Electrodiagnostic System (LKC Technologies, Gaithersburg, MD) (Peachey and Ball, 2003; Zhu et al., 2007). Animals were dark adapted overnight and prepared for recordings under infrared illumination. Mice were anesthetized by intraperitoneal injection of ketamine $(50 \mathrm{mg} / \mathrm{kg})$ and xylazine $(5 \mathrm{mg} / \mathrm{kg})$. The body temperature of the animals was maintained between 36 and $37^{\circ} \mathrm{C}$ throughout the recordings with a heating pad and monitored by rectal temperature probe. Pupils were dilated for recordings with $1 \%$ atropine, and corneas were kept moist with application of $1 \%$ carboxymethylcellulose as needed throughout the procedure. Stimuli were brief white flashes delivered via a Ganzfeld integrating sphere, and signals were recorded with bandpass settings of $0.3-500 \mathrm{~Hz}$. After a $10 \mathrm{~min}$ stabilization period, an 11-step scotopic intensity series $\left(-3.60\right.$ to $0.39 \log \mathrm{cd} \cdot \mathrm{s} / \mathrm{m}^{2}$ stimulus) was recorded, which included rod specific and scotopic bright flash responses. After a 10 min light adaptation period on a steady white background $\left(2.30 \log \mathrm{cd} / \mathrm{m}^{2}\right)$, a five-step photopic intensity series was recorded $\left(0.39-2.82 \log \mathrm{cd} \cdot \mathrm{s} / \mathrm{m}^{2}\right.$ stimulus). Scotopic and photopic b-wave amplitudes and scotopic a-wave amplitudes were recorded for all flash intensities. After recordings, animals recovered from anesthesia in a warming chamber and were returned to their cages.

Morphometric analysis. Animals were anesthetized and perfusion fixed with $4 \%$ paraformaldehyde, and the eyes were dissected and paraffin embedded. Sections $(4 \mu \mathrm{m})$ through the entire retina were prepared and stained with hematoxylin and eosin for retinal morphometric analysis (Zhu et al., 2007). The thicknesses of the entire retina, the ONL, the inner nuclear layer (INL), and the inner plexiform layer were measured using image analysis software. For each of these parameters, measurements were performed in the same region of the retina to avoid the possibility of regional anatomic variation in the results. For each retinal section, triplicate measurements (100 $\mu \mathrm{m}$ apart) were taken in each hemisphere, centered at the midway point between the optic nerve and retinal periphery. The number of ganglion cells was determined per $250 \mu \mathrm{m}$ of ganglion cell layer in each hemisphere, centered at the midway point between the nerve and retinal periphery. Measurements were obtained from four sections each from three animals of each genotype, and the results are represented as mean \pm SEM.

Immunohistochemistry. Mice were killed, and eyes were removed and fixed in $4 \%$ paraformaldehyde for $30 \mathrm{~min}$. Retinas were dissected and embedded in $4 \%$ low-melting agarose in $0.01 \mathrm{M}$ PBS, and $60 \mu \mathrm{m}$ vibratome sections were obtained (VibratomeX-100 plus; TPI, St. Louis, $\mathrm{MO})$. The sections were blocked in $5 \%$ horse serum for $1 \mathrm{~h}$ and incubated in primary antibody diluted in PBS overnight at $4^{\circ} \mathrm{C}$. Primary antibodies and dilutions included anti-PKC $\alpha$ (1:100; Santa Cruz Biotechnology, Santa Cruz, CA), anti-calbindin D28 (1:100; Sigma, St. Louis, MO), anti- activator protein $2 \alpha$ (AP2 $\alpha)$ (1:10; Developmental Studies Hybridoma Bank, University of Iowa, Iowa City, IA), anti-glutamine synthetase (1: 100; Millipore Bioscience Research Reagents, Temecula, CA), antiCyclin D3 (1:50; Cell Signaling Technology, Beverly, MA), anti-Brn-3a (brain-specific homeobox/POU domain protein 3A) (1:200; Millipore Bioscience Research Reagents), anti-neurofilament 200 (1:100; Sigma), and anti-synaptophysin (1:1000; BD Biosciences, San Jose, CA). Sections were washed multiple times in PBS and then incubated in cyanine 3-conjugated secondary antibody diluted in PBS (1:500; Millipore Bioscience Research Reagents) for $1 \mathrm{~h}$ at room temperature. After additional washes in PBS, sections were mounted in Vectashield with $4^{\prime}, 6^{\prime}$ diamidino-2-phenylindole (Vector Laboratories, Burlingame, CA), coverslipped, and viewed using an LSM 510 confocal microscope (Zeiss, Jena, Germany) at $40 \times$. Images were captured with Zeiss LSM software.

To determine the percentage of AP $2 \alpha$-positive amacrine cells that expressed Ret, GFR $\alpha 1$, or GFR $\alpha 2$, vibratome sections from retinas of the respective reporter mice were immunostained with anti-AP $2 \alpha$ antibody and viewed with an LSM 510 confocal microscope. Two adjacent $20 \times$ images were captured from each side of the optic nerve, midway between the nerve and the periphery. The percentage of 100 consecutive AP2 $\alpha$ positive amacrine cells that also stained for GFP was recorded for each set of images. Counts were determined in three separate retinal sections from each of two animals (total of 1200 cells counted). Additional retinal sections were immunostained with the ganglion cell marker Brn-3a, and the same technique was used to determine the percentage of Brn-3apositive ganglion cell that expressed Ret, GFR $\alpha 1$, or GFR $\alpha 2$.

Electron microscopy. Tissues were fixed in modified Karnovsky's fixative $(2.5 \%$ glutaraldehyde and $2 \%$ paraformaldehyde in $0.1 \mathrm{~m}$ phosphate buffer, $\mathrm{pH} 7.4$ ) at $4^{\circ} \mathrm{C}$ overnight and postfixed in $1 \%$ osmium tetroxide for $1 \mathrm{~h}$. Fixed tissues were then dehydrated in a graded series of ethyl alcohol (30-100\%) and then embedded in Epon-Araldite mixture. Thin $(70-80 \mathrm{~nm})$ sections were placed on $2 \times 1 \mathrm{~mm}$ copper grids. Grids were stained with uranyl acetate and lead citrate. Sections were examined using a Hitachi (Tokyo, Japan) H 7500 transmission electron microscope, and micrographs were captured at 2000-25,000×.

Statistics. Differences in the morphological measurements were compared by the nonparametric ANOVA rank-sum test. ERG responses from mutant and control mice were compared using a Student's $t$ test. $p$ values $<0.05$ were considered significant.

\section{Results \\ Retinas from Ret hypomorphic $\left(\operatorname{Ret}^{D N /+}\right)$ mice are functionally abnormal}

The perinatal lethality of Ret-null mice precludes postnatal investigations, including those concerning retinal function. We recently generated Ret hypomorphic $\left(\operatorname{Ret}^{D N /+}\right)$ mice with severely reduced Ret activity that survive for several weeks after birth (Jain et al., 2004), thus enabling postnatal retinal evaluation. To test for the presence of retinal functional deficits in the $\operatorname{Ret}^{\mathrm{DN} /+}$ mice, we performed electroretinography, in which retinal aggregate field potential responses are recorded under dark-adapted (scotopic) and light-adapted (photopic) conditions. The scotopic responses are primarily rod driven, and the photopic responses are derived exclusively from cones. A typical scotopic response to a bright flash stimulus consists of an a-wave, mediated primarily by photoreceptors, and a b-wave, produced by cells of the inner retina, primarily ON-bipolar cells. ERGs were recorded from postnatal day 18 (P18) Ret $t^{D N /+}$ and wild-type (WT) mice to a light intensity response series under both scotopic and photopic conditions (a complete list of mouse genotypes and numbers used for ERG experiments is found in supplemental Table 1, available at www.jneurosci.org as supplemental material). Ret $^{\mathrm{DN} /+}$ mice displayed significantly reduced scotopic a- and b-waves and photopic b-waves (Fig. 1). The maximal scotopic b-wave was reduced $65 \%$ compared with wild type [wild type, $712.4 \pm 86.3 \mu \mathrm{V}$ $\left(\right.$ mean $\pm \mathrm{SD}$ ); $\left.\operatorname{Ret}^{\mathrm{DN} /+}, 249.0 \pm 50.2 \mu \mathrm{V} ; p<0.001\right]$, and the 

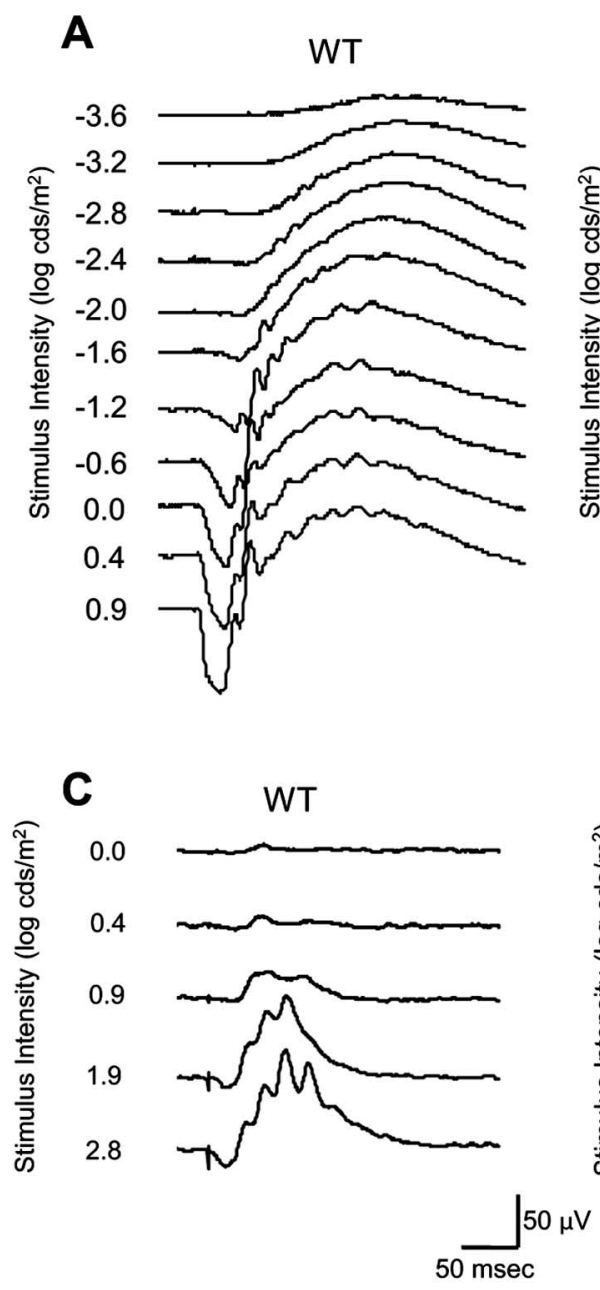
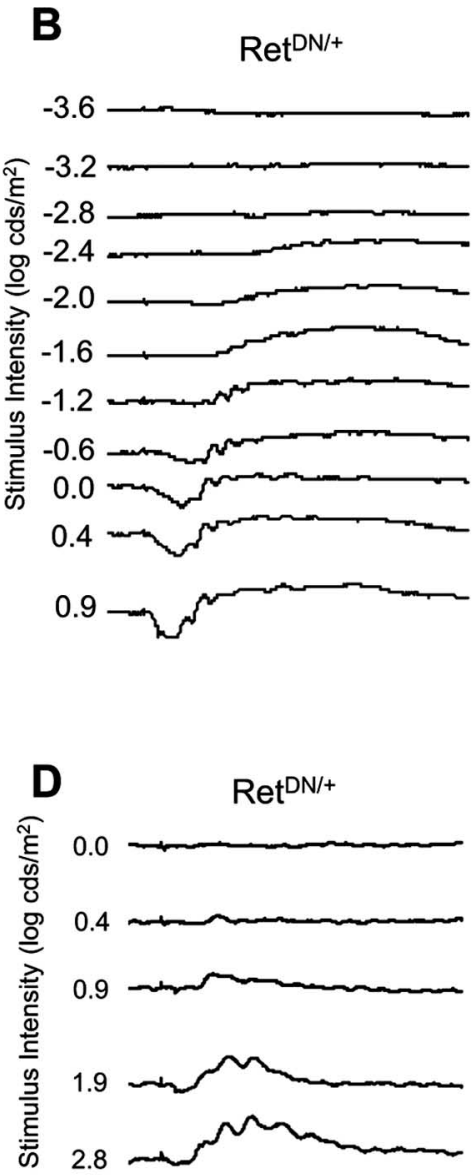

$0 \mu \mathrm{V}$
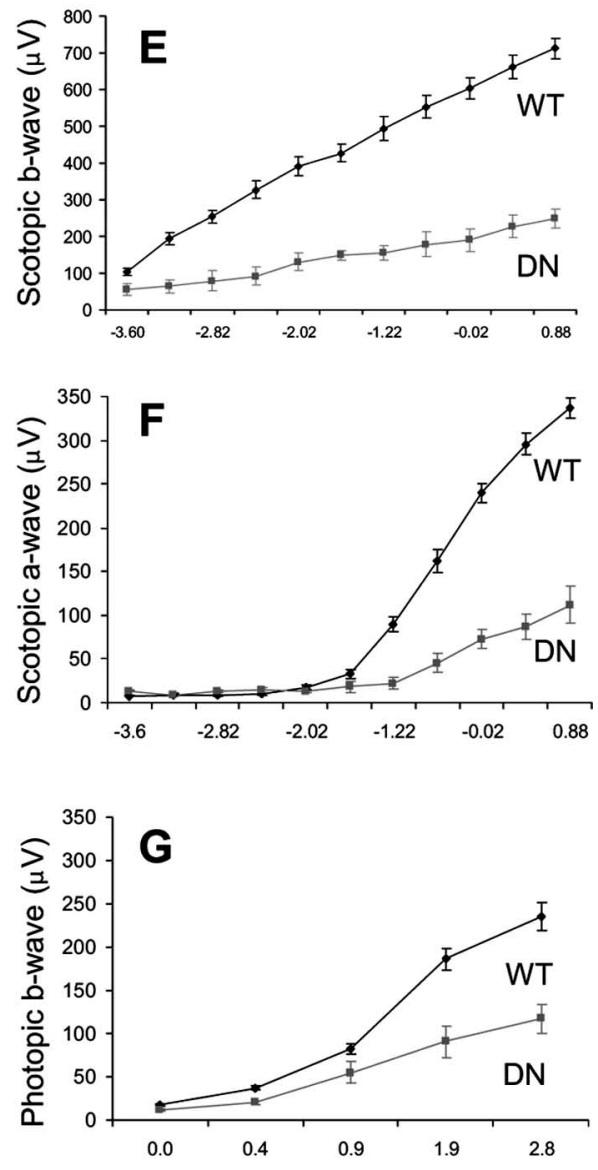

Stimulus Intensity $\left(\log \mathrm{cds} / \mathrm{m}^{2}\right)$

Figure 1. RET hypomorphic mice (Ret ${ }^{D N /+}$ ) have aberrant retinal function. Representative scotopic ERG waveforms recorded at increasing stimulus intensities from P18 WT $(\boldsymbol{A})$ and P18 Ret ${ }^{D N /+}$ $(\boldsymbol{B})$ mice. Note smaller waveforms in Ret ${ }^{D N+}$ mice, including reduced a-wave and b-waves. Photopic ERG waveforms from P18 Ret ${ }^{D N /+}$ mice $(\boldsymbol{C}, \boldsymbol{D})$ are attenuated. Quantitative depiction of ERGs from scotopic b-wave $(\boldsymbol{E})$ and a-wave $(\boldsymbol{F})$ and photopic b-wave $(\boldsymbol{G})$ of WT and Ret ${ }^{D N++}$ mice shows significantly reduced signals in the Ret ${ }^{D N /+}$ mice. DN, Ret ${ }^{D N++}$.

maximal photopic b-wave was reduced $50 \%$ compared with wild type (wild type, $234.9 \pm 50.5 \mu \mathrm{V} ; \operatorname{Ret}^{D N /+}, 117.2 \pm 33.7 \mu \mathrm{V} ; p=$ 0.001 ). These data imply abnormalities in both the rod and cone systems in $\mathrm{Ret}^{\mathrm{DN} /+}$ mice and suggest that RET activity is necessary during early life for the proper development and/or maintenance of global retinal function as assessed by electroretinography.

In a number of systems, aberrant RET signaling results in grossly abnormal development or altered tissue morphology (Schuchardt et al., 1994; Jain et al., 2004, 2006a; Arighi et al., 2005; Enomoto 2005; Naughton et al., 2006). We therefore performed a morphological analysis of the retina from these mice to evaluate overall retinal development at birth and P18, because the retina is nearly mature at this age and the $\operatorname{Ret}^{\mathrm{DN} /+}$ mice do not survive beyond 3 weeks. At the light microscopic level, no differences in retinal organization were observed between retinas from $\operatorname{Ret}^{\mathrm{DN} /+}$ and control mice at birth or at P18 (supplemental Fig. 1, available at www.jneurosci.org as supplemental material). Morphometric analysis to determine the number of ganglion cells as well as to measure the thicknesses of the different retinal layers, including the outer and inner nuclear layers, the inner plexiform layer, and the entire retina, also failed to reveal any abnormalities in $\operatorname{Ret}^{D N /+}$ retinas (supplemental Fig. 1, available at www. jneurosci.org as supplemental material).

\section{Neurturin is required for normal retinal function}

RET is the common receptor for all GFLs; thus, the deficits in Ret hypomorphic mice imply that one or more GFLs are required for proper retinal development and/or function. To determine which GFLs are critical for normal retinal function, we performed ERGs on adult $\mathrm{NRTN}^{\prime-}, \mathrm{ARTN}^{-1-}, \mathrm{PSPN}^{\prime-}$, and GDNF${ }^{+/-}$animals $\left(G D N F^{-1-}\right.$ mice could not be evaluated because of perinatal lethality). Scotopic aand b-waves and photopic b-waves for adult $A R T N^{--}, \mathrm{PSPN}^{-/}$, and $G D N F^{+/-}$mice were not significantly different from age-matched wildtype mice (Fig. 2). In contrast, adult $N R T N^{-1}$ mice exhibit severely diminished amplitudes of scotopic a- and b-waves and photopic b-wave (Fig. 2). The mean maximal scotopic b-wave (wild type, $703.5 \pm 64.7$ $\left.\mu \mathrm{V} ; \mathrm{NRTN}^{-1-}, 305.7 \pm 81.7 \mu \mathrm{V} ; p<0.001\right)$ and the mean maximal photopic b-wave (wild type, $254.4 \pm 48.7 \mu \mathrm{V} ; \mathrm{NRTN}^{-}{ }^{-}, 116.4 \pm 30.7$ $\mu \mathrm{V} ; p=0.001$ ) were both reduced $55 \%$ compared with wild type, indicating deficits exist in both the rod and cone systems. The reduction in the scotopic a-wave by $50 \%$ (wild type, $314.0 \pm 27.5 \mu \mathrm{V} ; \mathrm{NRTN}^{\prime-}$, $157.9 \pm 35.7 \mu \mathrm{V} ; p<0.001$ ) suggests that photoreceptor function is also altered in $N R T N^{-1}$ mutants. Together, these results indicate that NRTN is required whereas PSPN and ARTN are dispensable for normal retinal function. If GDNF is required, our results imply that a single functioning GDNF allele is sufficient to maintain normal function.

In the enteric nervous system, NRTN is implicated in mainte- 


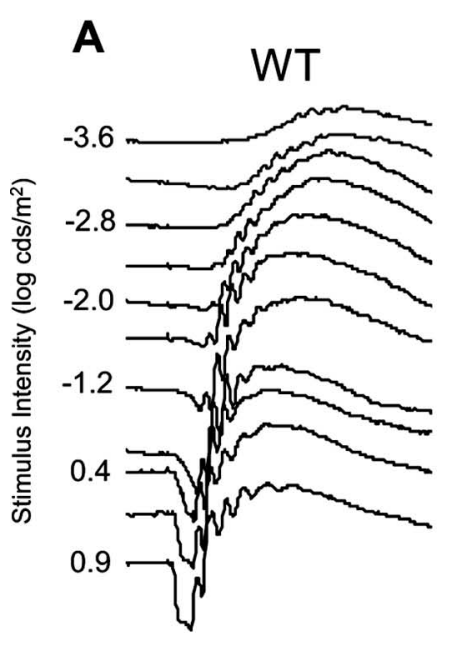

\section{$\mathrm{GDNF}^{+/-}$}
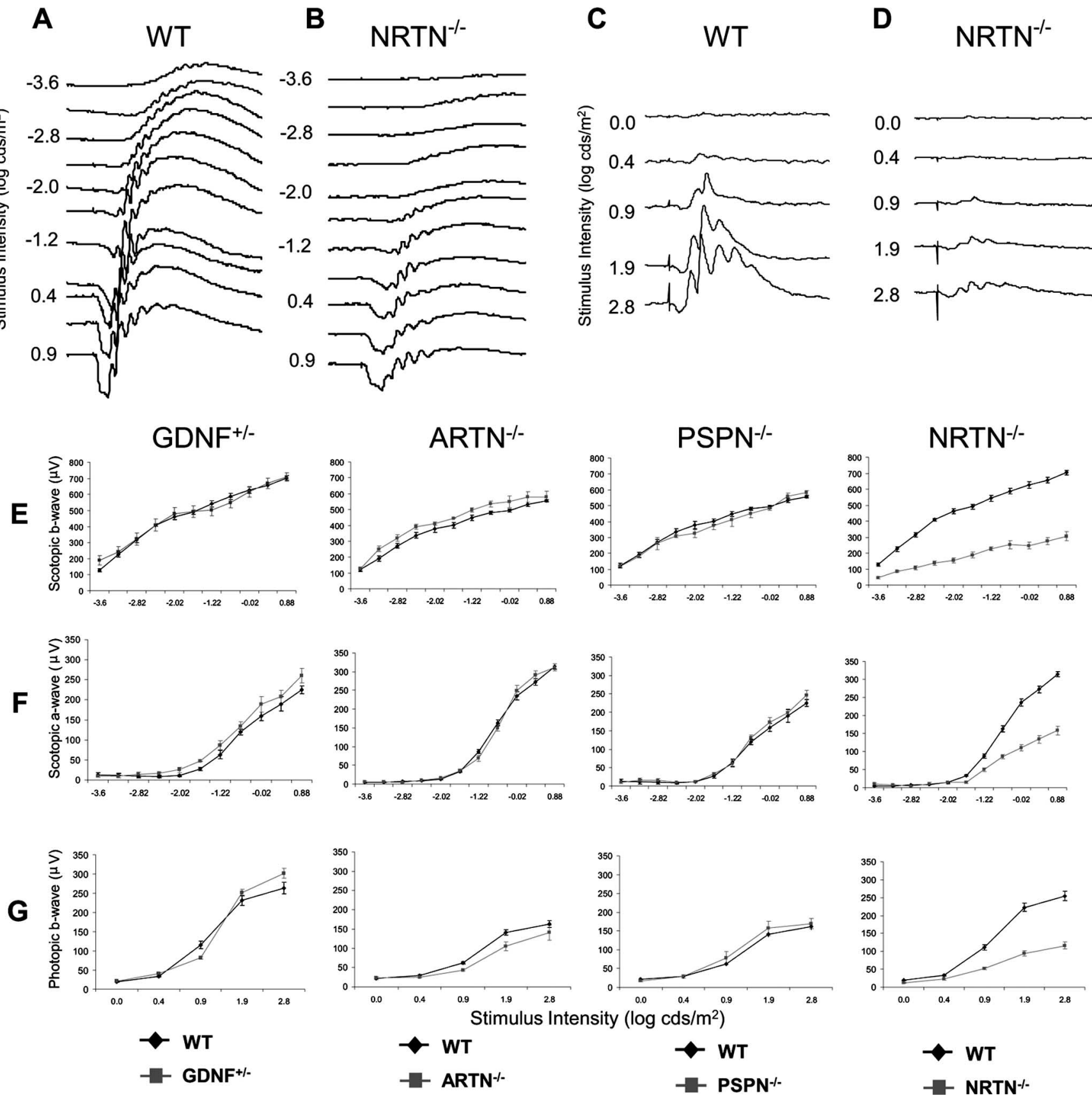

Figure 2. NRTN-deficient mice have abnormal retinal activity. Representative scotopic ERG waveforms recorded at increasing stimulus intensities from P60 WT $(\boldsymbol{A})$ and NRTN ${ }^{-/-}(\boldsymbol{B})$ mice. Note smaller waveforms in $N R T N^{-/-}$mice, including reduced a-waves and b-waves. Photopic ERG waveforms are attenuated in P60 NRTN ${ }^{-1-}$ mice $(\boldsymbol{C}, \boldsymbol{D})$. Quantitative depiction of ERGs from scotopic b-wave $(\boldsymbol{E})$, scotopic a-wave $(\boldsymbol{F})$, and photopic b-wave $(\boldsymbol{G})$ from adult $\mathrm{GDNF}^{+/-}, \mathrm{ARTN}^{-/-}, \mathrm{PSPN}^{-/-}$, and $\mathrm{NRTN}^{-/-}$mice show normal mean amplitudes for all recordings from GDNF ${ }^{+\prime-}$, $A R T N^{-1-}$, and $P S P N^{-/-}$mice but display significantly reduced amplitudes for all three waveforms in $N R T N^{-1-}$ mice.

nance of the neurons in adulthood, whereas GDNF is important during embryonic development. To determine whether NRTN is important during retinal maturation or only for maintenance in adult mice, we performed ERGs on P18 $\mathrm{NRTN}^{-1-}$ mice. Recordings from these mice showed a marked decrease in amplitude of the scotopic a- and b-waves and the photopic b-wave similar to those observed in the Ret ${ }^{D N /+}$ mice (supplemental Fig. 2, available at www. jneurosci.org as supplemental material). The similar ERG abnormalities of the Ret ${ }^{D N /+}$ and $N R T N^{-/-}$mice suggest that NRTN is the predominant, if not only, GFL critical for normal retinal function and that NRTN-Ret signaling is important for early retinal function.

To determine whether the impact of NRTN loss on retinal function resolves or becomes more severe with increasing age, we performed ERGs in 12-month-old NRTN $^{-1-}$ mice (supplemental Fig. 2, available at www.jneurosci.org as supplemental material). The scotopic a- and b-waves and photopic b-wave amplitudes for these mice were reduced to a similar extent as observed in younger animals. From these results, we conclude that NRTN is required during retinal development for the establishment of normal retinal function but that its absence does not lead to progressive functional loss throughout life.

Because $\mathrm{NRTN}^{-1}$ mice display significant retinal dysfunction throughout life by electrophysiology, we examined their retinas for anatomic abnormalities. As observed for Ret ${ }^{D N /+}$ mice, routine morphometric analysis revealed no difference in thicknesses of the outer and 

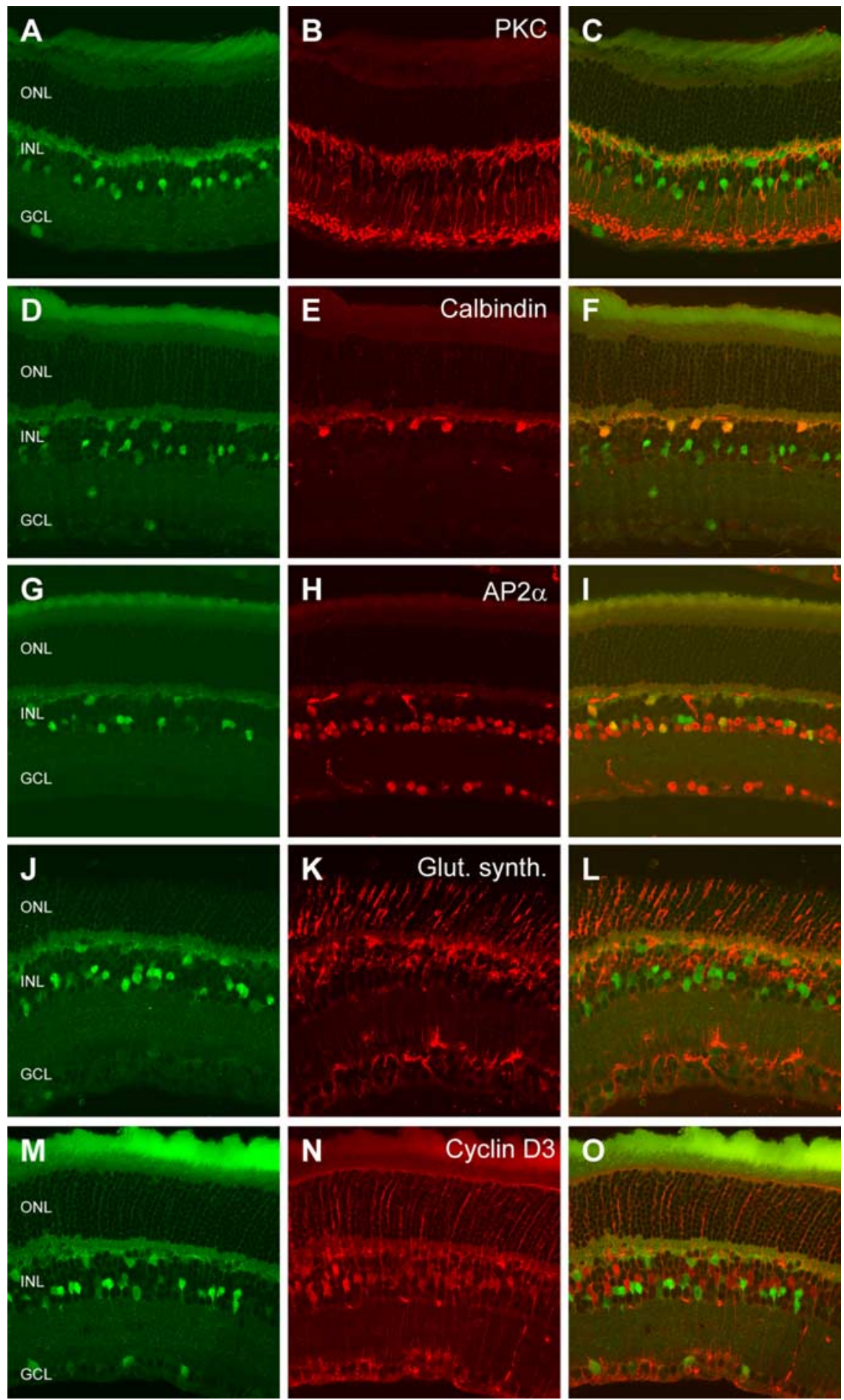

Figure3. RET is expressedinall horizontal cells and in a subset of amacrineand ganglioncells. Vibratomesections of retinafrom Ret ${ }^{E G F P /+}$ mice were immunostained with antibodies directed against markers of specific retinal cell types. Left column, Confocal images $(A, D, G, J, M)$ of retinal sections depicting direct green fluorescence (EGFP) (indicating RET expression) in retinal cells. Middle column, Confocal images $(B, E, H, K, N)$ of these same fields immunostained with the indicated antibody. Right column, Merged images $(\boldsymbol{C}, \boldsymbol{F}, \boldsymbol{I}, \boldsymbol{L}, \mathbf{O})$ from the left and middle columns. Colocalization of EGFP and anti-calbindin $(\boldsymbol{F})$ and anti-AP2 $\alpha(I)$ shows that RET is expressed in all horizontal cells and a subset of amacrine cells, respectively. EGFP signal is also detected in ganglion cells $(\boldsymbol{A}, \boldsymbol{D}, \boldsymbol{M})$. No colocalization is seen with anti-PKC $(\boldsymbol{C})$, demonstrating that Ret is not expressed in rod bipolar cells. Colocalization is also not seen with either anti-glutamine synthetase $(\boldsymbol{L})$ or anti-Cyclin D3 $(\mathbf{0})$, showing that Ret is not expressed in Müller glial cells. GCL, Ganglion cell layer.

inner nuclear layers, inner plexiform layer, or entire retina in the $\mathrm{NRTN}^{-1}$ mice compared with wild-type mice (supplemental Fig. 3, available at www.jneurosci.org as supplemental material). On more rigorous evaluation, the OPL appeared disorganized in $\mathrm{NRTN}^{--}$mice, suggesting the possibility that aberrations in micro-organization of this region (see below) could contribute to the observed retinal functional deficits.

RET is expressed by horizontal, amacrine, and ganglion cells

To determine the cellular basis for the defects in retinal function observed in mice with aberrant RET signaling, we investigated the expression pattern of Ret and the pertinent GFR $\alpha$ coreceptors in the retina. The cell-typespecific expression of these receptors has been unclear because the techniques and reagents used have led to conflicting results. For example, Ret, GFR $\alpha 1$, and GFR $\alpha 2$ have been variably detected in multiple cell types, including photoreceptors, inner retinal cells, and Müller glia (Jomary et al., 1999, 2004; Harada et al., 2002; Karlsson et al., 2002; Koberle and Ball 2002; Rothermel et al., 2004; Kretz et al., 2006). Reporter molecules expressed from endogenous loci have been successfully used to recapitulate and study native gene expression. Therefore, to unequivocally localize Ret expression, we used mice that express EGFP reporter from the endogenous Ret locus $\left(\operatorname{Ret}^{E G F P /+}\right)$ (Jain et al., 2006b). In wholemount retina sections, EGFP expression (and thus Ret expression) was detected in cells of the INL and ganglion cell layer in $\operatorname{Ret}^{E G F P /+}$ mice. Notably, no EGFP signal (hence no Ret expression) was detected in photoreceptor cell bodies. To identify the cell types in the INL that express Ret, we performed immunohistochemical colocalization studies with well established markers of bipolar, horizontal, amacrine, and Müller cells (Fig. 3). These studies demonstrated that Ret is not expressed in rod bipolar cells (identified with PKC immunohistochemistry) or in Müller glial cells, whose processes are identified by glutamine synthetase immunohistochemistry, and cell bodies are identified with Cyclin D3 immunohistochemistry (Dyer and Cepko, 2000; Rhee et al., 2007). However, EGFP was found in all calbindin D28-positive cells (labels horizontal cells) and AP2 $\alpha$-positive cells (labels amacrine cells) (Bassett et al., 2007) (Fig. 3). Quantitative analysis of colocalization with cell-specific markers demonstrated that Ret was expressed in $18 \%$ of AP $2 \alpha$-positive amacrine cells and $21 \%$ of Brn-3a-positive ganglion cells (data not shown).

\section{Overlapping and unique cell-type-}

specific expression of GFR $\alpha 1$ and GFR $\alpha 2$ coreceptors in the retina

GFR $\alpha 2$ is expressed in amacrine and ganglion cells

NRTN-mediated RET signaling is required for proper retinal function. We next sought to identify the GFR $\alpha$ coreceptor that might be physiologically relevant in this signaling pathway. Be- 
cause Ret was detected in multiple cell types, our approach was to identify the coreceptor that is expressed in the same cell type as Ret. NRTN can signal through both GFR $\alpha 1$ and GFR $\alpha 2$; however, GFR $\alpha 2$ is the preferred physiologic coreceptor for NRTN. Therefore, we first examined GFR $\alpha 2$ expression. We used reporter mice that express GFP from the Gfr $\alpha 2$ locus ( $G f r \alpha 2^{G F P /+}$ ) to identify the retinal cell types that express this coreceptor. We detected GFP (and thus GFR $\alpha 2$ ) expression in a subset of cells of the inner nuclear layer and ganglion cell layer (Fig. 4). Quantitative analysis of colocalization with cell-specific markers showed that GFR $\alpha 2$ was expressed in $12 \%$ of AP $2 \alpha$-positive amacrine cells and $7 \%$ of Brn-3a-positive ganglion cells (data not shown). Similar to our observations with Ret localization, GFR $\alpha 2$ was not found in photoreceptors, rod bipolar cells, or Müller glial cells. Surprisingly, GFR $\alpha 2$ was also absent from horizontal cells (Fig. 4), a cell type that expressed Ret, suggesting that GFR $\alpha 2$ does not directly activate NRTN-Ret signaling in horizontal cells.

GFR $\alpha 1$ is expressed in horizontal, amacrine, and ganglion cells

Given the abnormal appearance of the OPL in $\mathrm{NRTN}^{-1-}$ mice by light microscopy and the fact that Ret localizes to only one of the participants of the OPL synaptic triad (the horizontal cell), it is plausible that Ret signaling in horizontal cells is critical to proper OPL formation. However, we did not detect GFR $\alpha 2$ in horizontal cells, suggesting that NRTN may be signaling through the GFR $\alpha 1-$ Ret receptor complex in the retina. We therefore examined the expression pattern of GFR $\alpha 1$ using mice that express EGFP from the GFR $\alpha 1$ locus (Uesaka et al., 2007) and found that GFR $\alpha 1$ is expressed in all horizontal cells as well as in subsets of AP2 $\alpha$-positive amacrine cells and ganglion cells but not in rod bipolar cells or Müller glia (Fig. 5). Quantitative analysis of colocalization with cell-specific markers showed that GFR $\alpha 1$ was present in $21 \%$ of $\operatorname{AP} 2 \alpha$ positive amacrine cells and $17 \%$ of Brn-3apositive ganglion cells (data not shown). GFR $\alpha 1$ and Ret expression patterns are thus very similar in the retina compared with GFR $\alpha 2$ and Ret. These studies suggest that GFR $\alpha 1-$ Ret complexes could be the physiological mediators of NRTN signaling in horizontal cells.

\section{$\mathrm{NRTN}^{-1-}$ mice display aberrant outer} retinal synapses

The abnormal ERGs observed in $\operatorname{Ret}^{\mathrm{DN} /+}$ and $\mathrm{NRTN}^{-/-}$mice suggest abnormalities in photoreceptor/bipolar cell transmission. However, the absence of Ret expression in those cells suggests that Ret signaling indirectly modulates their interactions. Notably, the integrity of the synaptic
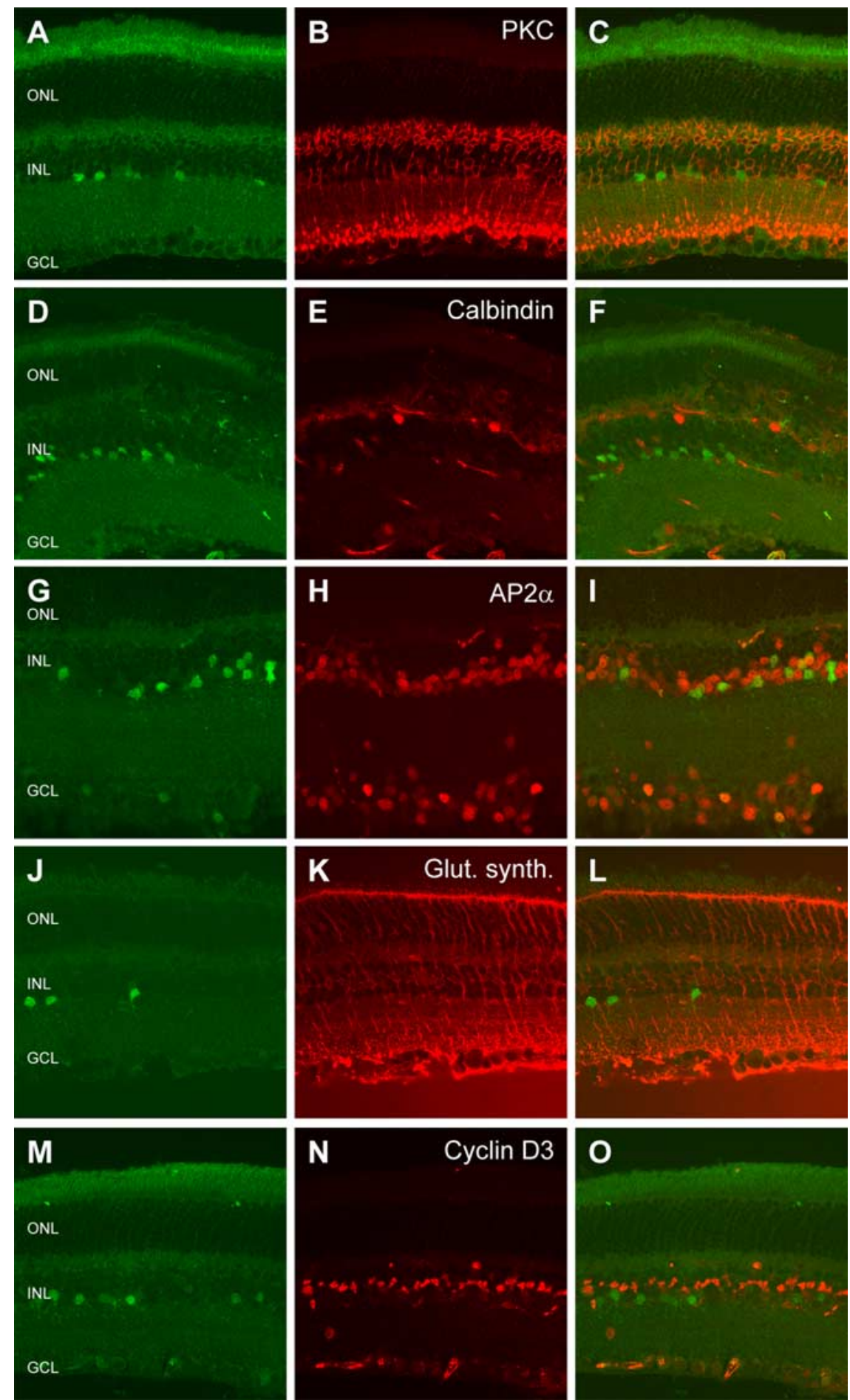

Figure 4. GFR $\alpha 2$ is expressed in a subset of amacrine and ganglion cells. Vibratome sections of retina from GFR $\alpha 2^{G F P /+}$ mice were immunostained with antibodies directed against markers for specific retinal cell types. Left column, Confocal images $(\boldsymbol{A}, \boldsymbol{D}$, $\boldsymbol{G}, \boldsymbol{J}, \boldsymbol{M}$ ) of retinal sections depicting green fluorescence (GFP) (indicating GFR $\alpha 2$ expression) in retinal cells. Middle column, Confocal images $(\boldsymbol{B}, \boldsymbol{E}, \boldsymbol{H}, \boldsymbol{K}, \boldsymbol{N})$ of these same fields immunostained with the indicated antibody. Right column, Merged images $(\boldsymbol{C}, \boldsymbol{F}, \boldsymbol{I}, \boldsymbol{L}, \mathbf{O})$ from the left and middle columns. Colocalization of GFP and anti-AP2 $\alpha(I)$ shows that GFR $\alpha 2$ is expressed in a subset of amacrine cells. GFP signal is also detected in ganglion cells $(\boldsymbol{G}, \boldsymbol{M})$. No colocalization is seen with anti-PKC $(\boldsymbol{C})$, demonstrating that GFR $\alpha 2$ is not expressed in rod bipolar cells. Colocalization is also not seen with either anti-glutamine synthetase $(\boldsymbol{L})$ or anti-Cyclin D3 (0), showing that GFR $\alpha 2$ is not expressed in Müller glial cells. GCL, Ganglion cell layer.

triad of the OPL, which is crucial for feedforward as well as feedback signaling, depends on dendrites of horizontal cells (which express Ret and GFR $\alpha 1$ ), bipolar cells, and rod spherules or cone pedicles. In mice with mutations that cause aberrant synaptic transmission between pho- 


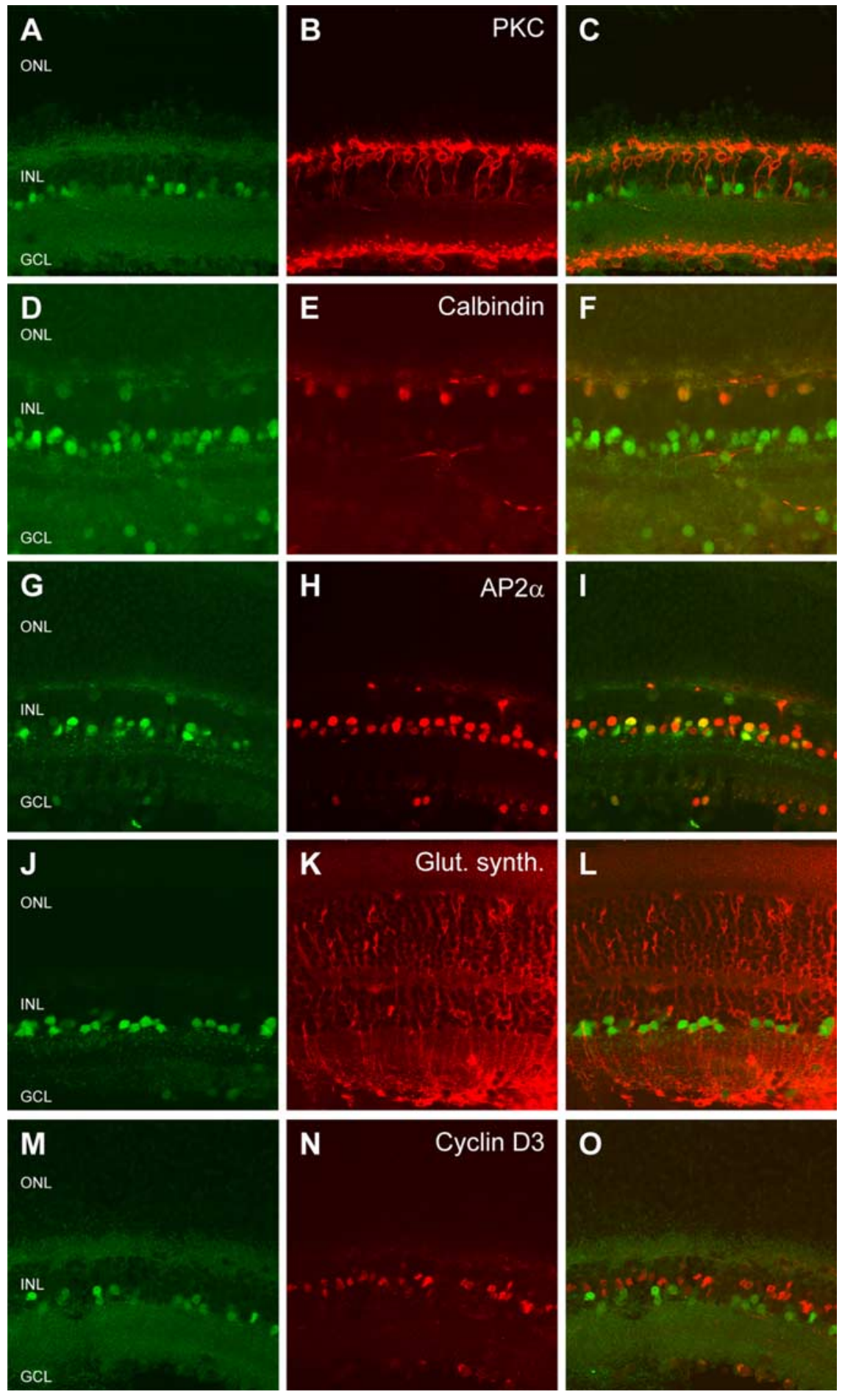

Figure 5. GFR $\alpha 1$ is presentin all horizontal cells and a subset of amacrine and ganglion cells. Vibratome sections of retina from GFR $\alpha 1^{\text {EGFP/+ }}$ mice were immunostained with antibodies directed against specific markers of retinal cell types. Left column, Confocal images $(A, D, G, J, M)$ of retinal sections depicting green fluorescence (EGFP) (indicating GFR $\alpha 1$ expression) in retinal cells... Middle column contains confocal images $(\boldsymbol{B}, \boldsymbol{E}$, $\boldsymbol{H}, \boldsymbol{K}, \boldsymbol{N})$ of these same fields immunostained with the indicated antibody. Right column contains merged images $(\boldsymbol{C}, \boldsymbol{F}, \boldsymbol{I}, \boldsymbol{L}, \boldsymbol{O})$ from the left and middlecolumns. Colocalization ofEGFPandanti-calbindin $(\boldsymbol{F})$ andanti-AP2 $\alpha(\boldsymbol{I})$ showsthatGFR $\alpha 1$ is expressed inall horizontal cells and asubset of amacrine cells. EGFP signal is also detected in ganglion cells $(\boldsymbol{D}, \mathbf{G}, \mathbf{J})$. No colocalization is seen with anti-PKC ( $(\mathbf{C})$, demonstrating that GFR $\alpha 1$ is not expressed in rod bipolar cells. Colocalization is also not seen with either anti-glutamine synthetase $(\boldsymbol{L})$ or anti-Cyclin D3 $(\mathbf{0})$, showing that GFR $\alpha 1$ is not expressed in Müller glial cells. GCL, Ganglion cell layer.

toreceptors and bipolar cells [e.g., $\mathrm{Bsn}^{-/-}$(bassoon), nob2 (no b-wave 2), and $R_{s} 1 h^{-/-}$(retinoschisin) mice], the bipolar and horizontal cell dendrites are often abnormally elongated such that their tips extend well into the outer nuclear layer (Dick et al., 2003; Chang et al., 2006; Johnson et al., 2006; Bayley and Morgans, 2007). To determine whether similar bipolar or horizontal dendrite abnormalities exist in $\mathrm{NRTN}^{-1-}$ mice, we stained these cells with PKC and calbindin antibodies and visualized retinas using highresolution confocal microscopy. We found significantly elongated rod bipolar and horizontal cell processes in the $\mathrm{NRTN}^{-1}$ mice compared with wild-type animals (Fig. 6), suggesting that NRTN-mediated Ret signaling is critical for proper formation of the synaptic triad in the outer plexiform layer and that abnormal formation of the synaptic triad may contribute to the abnormal ERGs observed in these mice.

Horizontal cells in the mouse retina have two types of neurites that make connections with photoreceptor termini: axons that synapse with rod spherules and dendrites that synapse with cone pedicles (Peichl and Gonzalez-Soriano, 1994). Calbindin antibodies stain horizontal cell bodies and dendrites but do not stain horizontal cell axons. Immunostaining of retinas from $N R T N^{-1-}$ mice with calbindin antibodies (Fig. 6) revealed normal horizontal cell body morphology and location but showed that the dendritic plexus contains multiple gaps and is very sparse compared with the wild-type retina. To determine whether both horizontal cell dendrites and axons are affected in $N R T N^{-1-}$ mice, we colabeled these retinal sections with calbindin and a marker for horizontal cell axons, neurofilament 200 (Peichl and Gonzalez-Soriano, 1993; Gargini et al., 2007). We found that horizontal cell axons were also severely affected in $N R T N^{-/-}$mice, with much less staining in the inner portion of the OPL in which horizontal cells contact cone pedicles (Fig. 7). These observations confirm that both horizontal cell dendrites and axons are abnormal in $N R T N^{-/-}$mice.

To determine whether these abnormal bipolar and horizontal cell processes were involved in aberrant synapse formation in the ONL of $\mathrm{NRTN}^{-/-}$mice, we stained retinal sections with an antibody directed against synaptophysin, an integral membrane protein in synaptic vesicles found in the terminals of photoreceptors (Sharma et al., 2003). We identified a large number of mislocalized synaptic vesicles within the ONL of $N_{R T N}{ }^{-1-}$ mice, whereas none were seen in the wild-type retina (Fig. 8). To determine whether synaptic ribbon structures were present within the ONL, we performed electron microscopy on retinal sections from $\mathrm{NRTN}^{-/-}$mice. Micrographs revealed a severely abnormal OPL with regions of direct juxtaposition of inner and outer nuclear cell bodies as well as numerous synaptic ribbons deep within the ONL (Fig. 8). These studies confirm that synaptic ribbons are aberrantly located in the ONL in $N R T N^{-/-}$mice, suggesting that the 
abnormalities in horizontal and bipolar cell processes in synapse formation in the ONL cause abnormal photoreceptor to bipolar cell signaling and contribute to the ERG defects.

\section{Adult mice lacking retinal RET expression have functional and anatomical abnormalities}

Because $\operatorname{Ret}^{\mathrm{DN} /+}$ mice die before reaching P21, we were unable to evaluate the retinal phenotype in these mice as adults. To determine whether adult mice devoid of Ret signaling in the retina share the same functional and morphologic phenotypes as $N R T N^{-/-}$mice, we generated mice that delete Ret specifically in the retina. Mice harboring a RET conditional allele, RETfloxEGFP (Jain et al., 2006b), were mated to retina-specific Cre (Six3Cre) mice. Ret was efficiently excised in these cells, as demonstrated by the expression of the EGFP reporter, which is activated when Ret is deleted in this construct (Jain et al., 2006b). We performed ERGs in 2-monthold Ret ${ }^{\text {RETfloxEGFP/RETfloxEGFP }}$ :Six3Cre mice and found that the scotopic a- and b-waves and photopic b-wave amplitudes for these mice were reduced to a similar extent as observed in $\mathrm{NRTN}^{-/-}$and $\mathrm{Ret}^{\mathrm{DN} /+}$ mice (Fig. 9). We stained these cells with PKC and calbindin antibodies and again found elongated rod bipolar and horizontal cell processes as observed in the $N R T N^{-1-}$ mice (Figs. 8, 9). Electron microscopy of retinas from $\operatorname{Ret}^{\text {RETfloxEGFP/RETfloxEGFP: }}$ Six3Cre mice revealed a disorganized OPL and synaptic ribbons within the ONL as in NRTN $^{-1-}$ mice (data not shown). Together, these functional and morphologic studies confirm that NRTN signaling in the retina is dependent on Ret signaling in the retina.

\section{Discussion}

GDNF prolongs photoreceptor cell survival in several animal models of retinal degeneration. It has been hypothesized that GDNF and other GFLs support photoreceptors indirectly by activating RET signaling in Müller glial cells, leading to the release of specific trophic factors that protect photoreceptors (Delyfer et al., 2005; Hauck et al., 2006). Also, in vitro studies in the chick have suggested a role for GDNF in the development and survival of photoreceptors (Rothermel and Layer, 2003). It remains unclear, however, what role GDNF or other GFLs may play in preserving retinal cells and their physiological function in vivo. There currently are limited data available regarding the function of GFLs, GFR $\alpha$ s, or RET in normal retinal development or maintenance. Our studies were designed to determine what role these molecules play in the normal retina by evaluating GFL- and Retdeficient mice both morphologically and functionally.

In investigating the role of Ret signaling on retinal function, we found that reduced or absent Ret signaling in mice results in severely abnormal ERG patterns, indicating that Ret is required for normal retinal function. The requirement for Ret signaling was evident at P18, suggesting that Ret is important for retinal development. In pursuing this idea, we found that the number of photoreceptor cell bodies in the ONL as well as in the inner and outer segments of the photoreceptors was normal in these mice, indicating that retinal dysfunction is not attributable to gross developmental anomalies or early degeneration of photoreceptors. Consistent with this result, we also were unable to detect expression of Ret or its coreceptors GFR $\alpha 1$ and GFR $\alpha 2$ in the photoreceptors.

Because RET is the common signaling component of the GFL receptor complex, its requirement for normal retinal function implies that one or more GFL is required for retinal development and/or function. In this regard, our electrophysiologic studies 

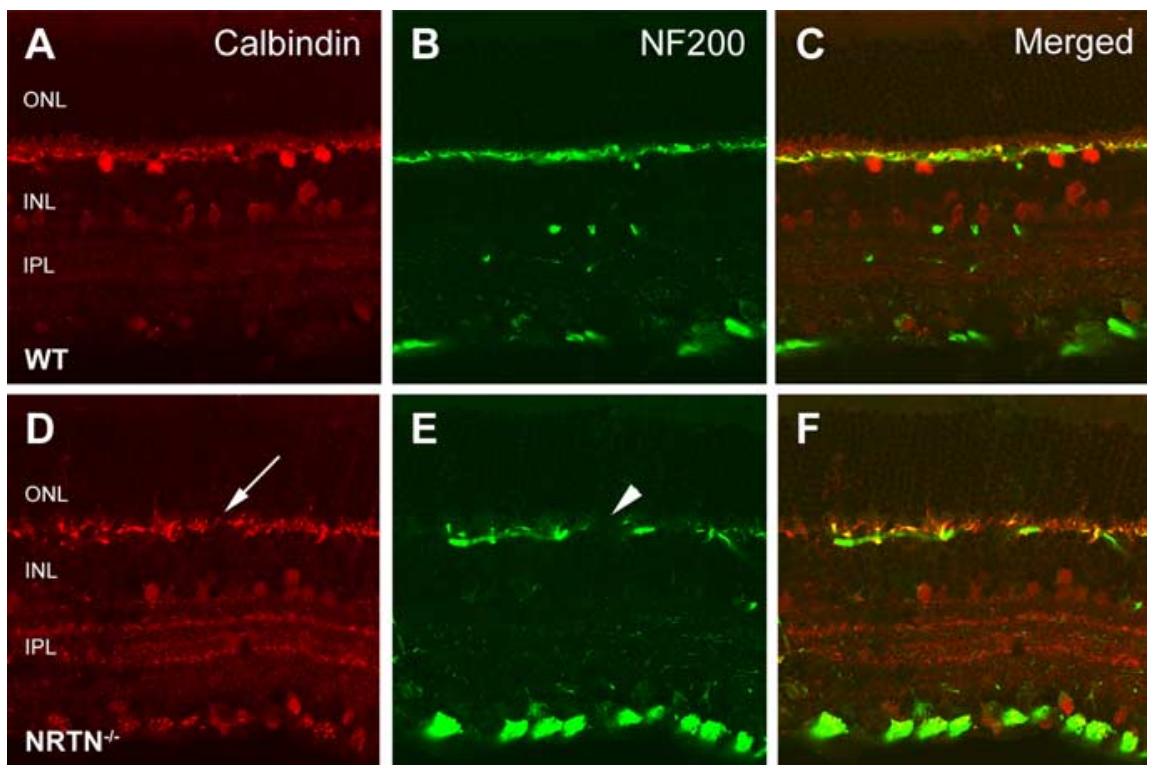

Figure 7. Horizontal cell axons are abnormal in NRTN ${ }^{-/-}$mice. Retinal sections from P60 WT $(\boldsymbol{A}-\boldsymbol{C})$ and NRTN ${ }^{-/-}(\boldsymbol{D}-\boldsymbol{F})$ animals immunostained with anti-calbindin to label horizontal cell bodies and dendrites and with anti-neurofilament 200 (NF200) to label horizontal cell axons show a decrease in the amount of dendrite (arrow) and axon (arrowhead) labeling in $\mathrm{NRTN}^{-1-}$ mice compared with WT mice. IPL, Inner plexiform layer.

showed that, of the GFLs, NRTN was necessary for normal retinal function, whereas ARTN and PSPN were dispensable. Retinal dependence on NRTN begins during retinal maturation and extends into adulthood. Although GDNF heterozygous mice had normal ERGs, we were unable to evaluate the $G D N F^{-/-}$mouse. Thus, it remains a possibility that GDNF-mediated RET signaling is also important for retinal function. However, two findings suggest that NRTN is the primary GFL involved in retinal function. First, physiologic GDNF does not preserve retinal function in $\mathrm{NRTN}^{-}$- mice. Second, the extent of retinal dysfunction in $N R T N^{-1-}$ mice was similar to that of both $\operatorname{Ret}^{\text {DN/+ }}$ and Ret $^{\text {RETfloxEGFP/RETfloxEGFP }}$ :Six 3 Cre mice. These findings suggest an essential role for NRTN in normal retinal function.

Because NRTN is a diffusible ligand, we focused on localizing its sight of action in the retina by identifying retinal cell types that express the relevant GFR $\alpha$ coreceptors and Ret. However, the site of NRTN expression in the retina remains of interest, with previous in situ hybridization studies in mice reporting diffuse NRTN expression in the retina (Jomary et al., 1999), whereas immunohistochemistry in rats has suggested the NRTN is expressed in the ganglion cell layer and inner nuclear layer (Harada et al., 2003). Additional in situ hybridization studies or experiments using NRTN-EGFP reporter mice with high-resolution sections will be needed to specifically identify the retinal cells that express NRTN.

Previous attempts to localize expression of GFR $\alpha$ coreceptors and Ret in the mouse retina have also produced inconsistent results, primarily attributable to variability in the antibodies or techniques used. To overcome this difficulty, we used mice in which a reporter (EGFP or GFP) was expressed from the respective receptor loci. This allowed a more definitive localization of receptor expression. Using this technique, we detected Ret in all horizontal cells and in subpopulations of amacrine and ganglion cells. Previous work in $r d 1$ (retinal degeneration) mice (Delyfer et al., 2005) and pigs (Hauck et al., 2006) has suggested a key role for Müller glial cells in Ret signaling. Using semiquantitative realtime PCR (Delyfer et al., 2005) or immunohistochemical tech- niques (Hauck et al., 2006), these studies localized GFR $\alpha$ coreceptors and Ret to Müller glial cells. In this study, we used a genetic approach and took advantage of mouse lines that express GFP reporters from receptor-expressing cells and highmagnification confocal microscopy to localize GFR $\alpha$ coreceptors and Ret to specific retinal cell types. We did not detect these receptors in Müller glia. Additionally, we did not identify Ret expression in photoreceptor cells bodies, confirming that Retmediated photoreceptor protection occurs indirectly. Because GFR $\alpha 2$ is the favored coreceptor for NRTN, we expected to find GFR $\alpha 2$ expression in the same cells that expressed Ret. However, GFR $\alpha 2$ expression was not detected in any horizontal cells and was present in a smaller percentage of amacrine and ganglion cells than was Ret. Because in vitro studies have demonstrated that NRTN can also signal through GFR $\alpha 1-$ RET complexes (Baloh et al., 1997; Jing et al., 1997), we examined retinal expression of GFR $\alpha 1$. Interestingly, we found that GFR $\alpha 1$ was primarily coexpressed with Ret in the retina, which leads us to hypothesize that NRTN may signal through GFR $\alpha 1-$ RET complexes in addition to or instead of GFR $\alpha 2$-RET complexes in the retina. Additional analysis of mice with GFR $\alpha 1$ and GFR $\alpha 2 \mathrm{mu}-$ tations will be necessary to definitively determine the role each of these coreceptors plays in retinal signaling.

Interestingly, both Ret and GFR $\alpha 1$, but not GFR $\alpha 2$, were detected in the horizontal cells, suggesting that these cells might be critical for GFL-mediated signaling in the retina. Additionally, $\mathrm{NRTN}^{-/}$mice displayed a thinned and disorganized OPL, suggesting abnormal synaptic connections among photoreceptors, bipolar cells, and horizontal cells. Previous studies using transgenic mice expressing the simian virus 40 early region under control of the phenylethanolamine- $N$-methyltransferase promoter to induce degeneration of the horizontal cells and the outer plexiform layer demonstrated that proper localization of functional horizontal cells is critical to normal OPL morphology (Hammang et al., 1993) as well as retinal electrophysiologic responses (Peachey et al., 1997). Proper horizontal cell migration during development could possibly be affected by retinal GFL signaling because it has been shown that GDNF and GFR $\alpha 1$ promote migration of cortical GABAergic neurons (Pozas and Ibáñez, 2005).

These observations led us to further scrutinize the morphology of the outer plexiform layer. We found that $N R T N^{-/}$and Ret $^{\text {RETfloxEGFP/RETfloxEGFP }}$ :Six3Cre mice displayed a paucity of axonal projections as well as highly aberrant bipolar and horizontal cell dendrites, suggesting that abnormal synapse organization, involving the photoreceptors, bipolar cells, and horizontal cells, is a contributing factor to retinal dysfunction in these mice. Interestingly, similar aberrant dendrites are seen in other mouse mutants with reduced photoreceptor-bipolar cell signaling, including nob2 mice, which have a mutation in the $\alpha$ subunit of a presynaptic voltage-dependent calcium channel (Chang et al., 2006; Bayley and Morgans, 2007) and mice deficient in $\mathrm{Ca}^{2+}$ binding protein 4 (CaBP4), which interacts with these calcium channels in photoreceptor termini (Haeseleer et al., 2004; Maeda 
et al., 2005). Abnormal elongation of bipolar and horizontal cell processes is also seen in mice with mutations in the Bsn and Rs $1 h$ genes (Dick et al., 2003; Johnson et al., 2006), as well as in response to photoreceptor degeneration in the RCS rat model of retinitis pigmentosa (Cuenca et al., 2005). If NRTN-mediated Ret signaling is crucial to the formation of properly localized functional synapses in the outer plexiform layer, the abnormal processes in these mutants could represent horizontal cell and bipolar cell dendrites extending into the outer nuclear layer in search of normal photoreceptor termini synaptic targets. Alternatively, these abnormal projections into the ONL may be, in part, remnants of the neuroepithelium-derived processes of developing bipolar cells (Morgan et al., 2006) that did not properly regress attributable to lack of NRTN signaling. Examination of bipolar cell and horizontal cell processes during retinal maturation will be necessary to determine the origin of these abnormal structures.

Additional investigation of the $N_{R T N}^{-1-}$ and Ret RETfloxEGFP/RETfloxEGFP: Six3Cre retinas revealed that presynaptic vesicle markers and synaptic ribbon structures are present among the photoreceptor cell bodies of the ONL in these mice. Such aberrantly located synapse structures are also seen in $\mathrm{Bsn}^{-1-}$ and nob2 mice (Dick et al., 2003; Chang et al., 2006; Bayley and Morgans, 2007). Recent studies in hippocampal neurons showed that GDNF triggers adhesion between GFR $\alpha 1$ expressing neurons, a critical step in appropriate synapse formation between these cells (Ledda et al., 2007). A similar, as-yet unknown mechanism could be involved in retinal synapse formation as well. Additional ultrastructural studies as well as immunohistochemical analysis using presynaptic and postsynaptic markers will be needed to better understand the structure of these mislocalized synapses and how they contribute to abnormal retinal function.

The ERGs of $\operatorname{Ret}^{\text {DN/+ }}$, Ret ${ }^{\text {RETfloxEGFP/ }}$ RETfloxEGFP: Six3Cre, and $N R T N^{-1-}$ mice showed a dramatic reduction in both scotopic and photopic b-wave amplitudes, indicating that both the rod and cone systems were affected in these mutants. The b-wave is driven primarily by the ON-bipolar cells, and any abnormality in ONL synapses would reduce the b-wave. In fact, the Rs1h and nob2 mutants display "electronegative" waveforms (Chang et al., 2006; Johnson et al., 2006; Bayley and Morgans, 2007), in which the b-wave amplitude is less than the a-wave amplitude. We also observed reduced a-waves in $\operatorname{Ret}^{\mathrm{DN} /+}$, Ret $^{\text {RETfloxEGFP/RETfloxEGFP }}$ :Six3Cre, and $N R T N^{-1-}$ mice. This was somewhat unexpected, given that the leading edge of the a-wave
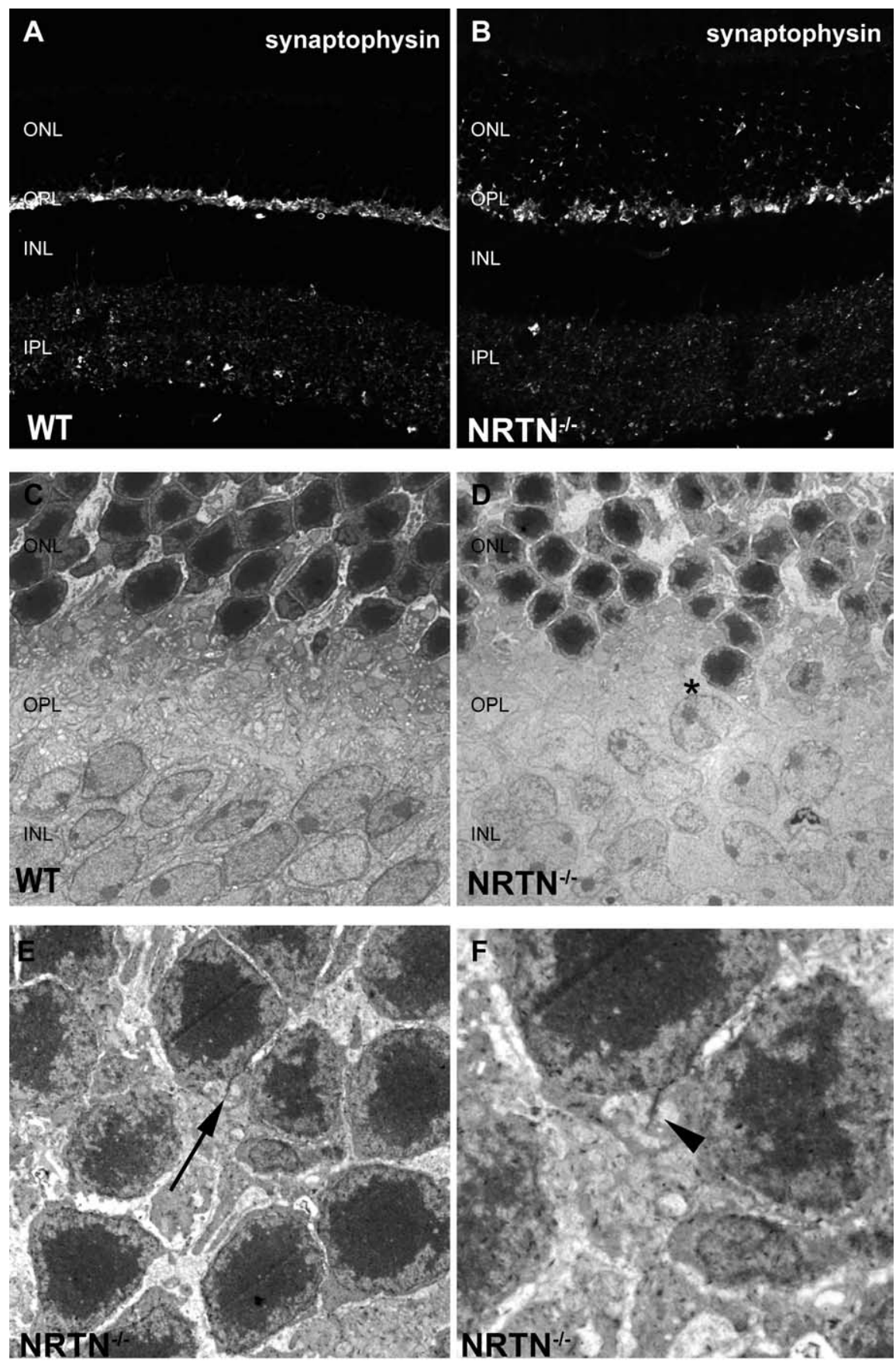

Figure 8. $\quad$ NRTN ${ }^{-/-}$mice have aberrant synapses within the outer nuclear layer. Vibratome sections of retina from P60 WT $(\boldsymbol{A})$ and RRTN $^{-/-}(\boldsymbol{B})$ animals immunostained with anti-synaptophysin to label presynaptic vesicles show that synapse structures are abnormally located in the ONL of NRTN ${ }^{-/-}$mice. Transmission electron microscopy on retina sections from P60 WT (C) and $N_{R T N}{ }^{-1-}(\boldsymbol{D})$ mice demonstrates that the OPL of the NRTN ${ }^{-1-}$ mice is ill-defined with close juxtaposition of cell bodies from the outer and inner nuclear layers (asterisk). $\boldsymbol{E}, \boldsymbol{F}$, Higher-power transmission electron microscopy shows synaptic ribbons (arrow, arrowhead) aberrantly located among the cell bodies in the ONL in NRTN ${ }^{-1-}$ mice. IPL, Inner plexiform layer.

is driven by photoreceptors, which appear normal in these mutants. There are several possibilities for this finding. First, it is known from pharmacologic studies in primates that there are post-receptor components to the a-wave (Jamison et al., 2001), and these components may be affected in the $\operatorname{Ret}^{\mathrm{DN} /+}$, Ret $^{\text {RETfloxEGFP/RETfloxEGFP }}$ :Six3Cre, and $N R T N^{-/-}$mutants. Second, the photoreceptors may appear normal anatomically, but their function could be affected by subtle changes in their 


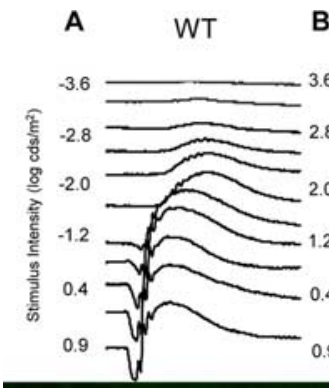

B $\operatorname{Ret}^{\mathrm{EGFP}}:$ Six $3 \mathrm{Cre}$

C

WT
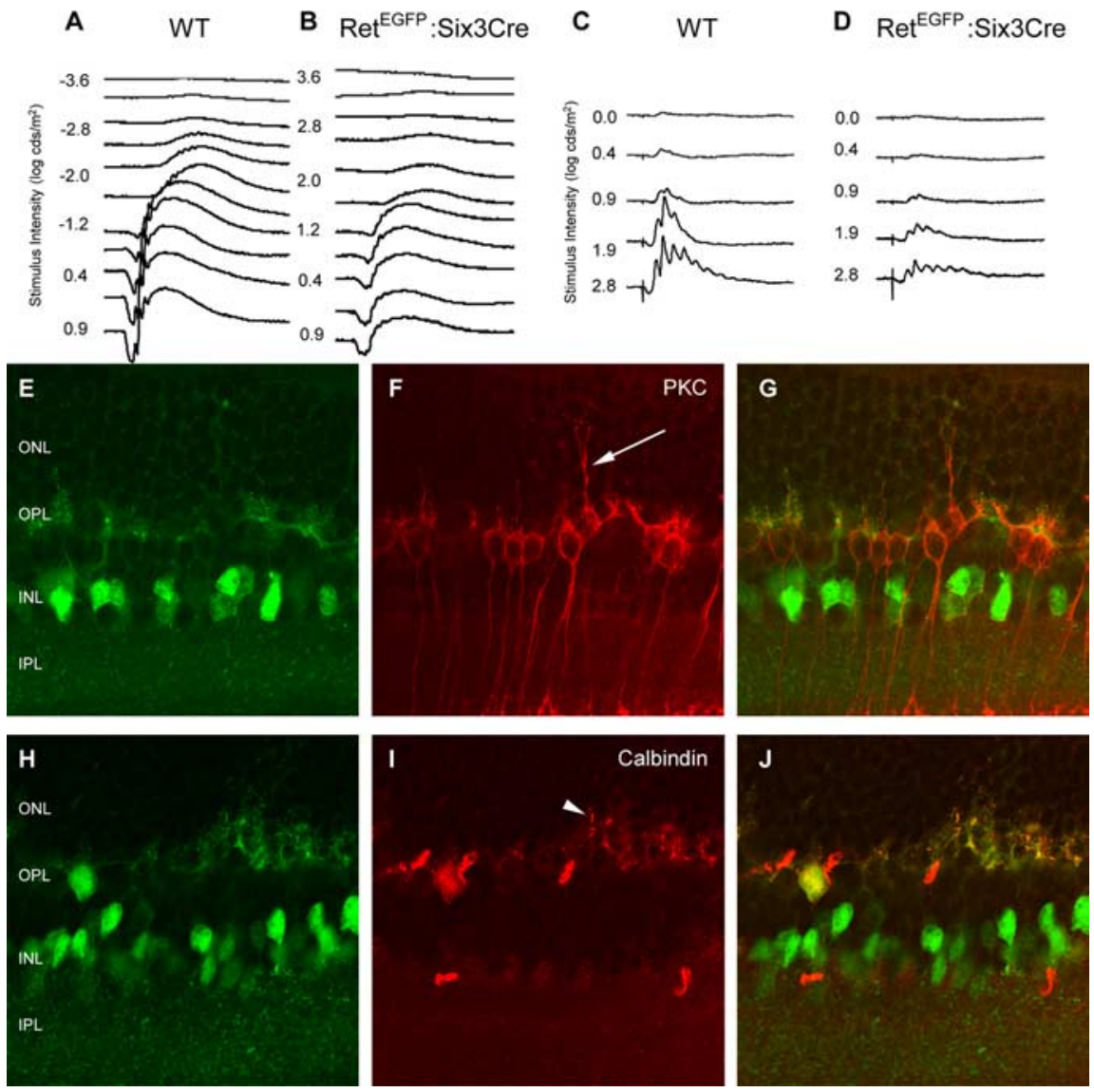

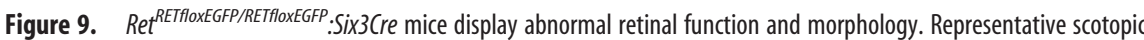
ERG waveforms recorded at increasing stimulus intensities from P45 WT $(\boldsymbol{A})$ and P45 Ret ${ }^{\text {REIfloxEGFP/REFfloxEGFP }}$ :Six3Cre $(\boldsymbol{B})$ mice. Note smaller waveforms in Ret ${ }^{\text {RETfloxEGFP/REFfloxEGFP. }}$ Six3Cre mice, including reduced a-wave and b-waves. Photopic ERG waveforms from Ret ${ }^{\text {REFfloxEGFPREEFfloxEGFP }}$ :Six3 Cre mice are also attenuated $(\boldsymbol{C}, \boldsymbol{D})$. Confocal images $(\boldsymbol{E}, \boldsymbol{H})$ of retinal sections from

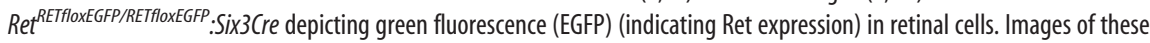
same fields immunostained with anti-PKC $(\boldsymbol{F})$ and anti-calbindin $(\boldsymbol{I})$ show abnormal projections from bipolar cells (arrow) and horizontal cells (arrowhead), respectively, into the outer nuclear layer. Merged images $(G, J)$ show that abnormal horizontal

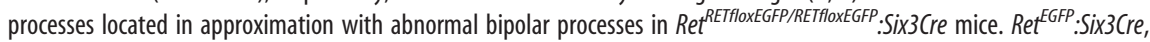

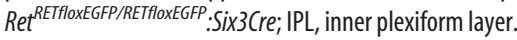

outer segments or might be influenced by abnormal signaling in the outer plexiform layer. For instance, the CaBP4 protein is localized to the photoreceptor cell termini, but $C a B P 4^{-1-}$ mice have both reduced a- and b-waves on ERGs (Haeseleer et al., 2004). Additional testing of photoreceptor and bipolar cell single-cell responses in NRTN-deficient mice will help determine how NRTN-RET signaling affects specific cell types and contributes to overall retinal function. Finally, NRTN may be important in maintaining a subset of amacrine cells that produce dopamine (Oiwa et al., 2002; Fjord-Larsen et al., 2005; Liu et al., 2007). Because dopamine has been implicated in various forms of retinal processing, including light adaptation (Marshak, 2001), horizontal cell coupling (He et al., 2000), and abnormalities in ERG b-wave amplitude (HuppeGourgues et al., 2005), an evaluation of the dopaminergic retinal cells in $N R T N^{-1-}$ mice could provide additional insight into the role of NRTN-RET signaling in retinal function.

In summary, we have shown that NRTN-mediated RET activation is important for normal retinal function through its actions on horizontal cells, a subpopulation of amacrine cells, and/or ganglion cells. Lack of GFR $\alpha 2$ expression in the cells of the OPL synaptic triad suggests that these effects may be mediated through alternative RET-GFR $\alpha$ complexes. The discovery that NRTNmediated RET activation is important for retinal activity may have therapeutic implication in treatment of retina-related diseases.

\section{References}

Andrieu-Soler C, Aubert-Pouessel A, Doat M, Picaud S, Halhal M, Simonutti M, VenierJulienne M-C, Benoit J-P, Behar-Cohen F (2005) Intravitreous injection of PLGA microspheres encapsulating GDNF promotes the survival of photoreceptors in the $r d 1 / r d 1$ mouse. Mol Vis 11:1002-1011.

Arighi E, Borrello MG, Sariola H (2005) RET tyrosine kinase signaling in development and cancer. Cytokine Growth Factor Rev $16: 441-467$.

Baloh RH, Tansey MG, Golden JP, Creedon DJ, Heuckeroth RO, Keck CL, Zimonjic DB, Popescu NC, Johnson Jr EM, Milbrandt J (1997) TrnR2, a novel receptor that mediates neurturin and GDNF signaling through Ret. Neuron 18:793-802.

Baloh RH, Enomoto H, Johnson Jr EM, Milbrandt J (2000) The GDNF family ligands and receptors-implications for neural development. Curr Opin Neurobiol 10:103-110.

Bassett EA, Pontoriero GF, Feng W, Marquardt $\mathrm{T}$, Fini ME, Williams T, West-Mays JA (2007) Conditional deletion of activating protein $2 \alpha(\mathrm{AP}-2 \alpha)$ in the developing retina demonstrates non-cell-autonomous roles for AP- $2 \alpha$ in optic cup development. Mol Cell Biol 27:7497-7510.

Bayley PR, Morgans CW (2007) Rod bipolar cells and horizontal cells form displaced synaptic contacts with rods in the outer nuclear layer of the nob2 retina. J Comp Neurol 500:286-298.

Carwile ME, Culbert RB, Sturdivant RL, Kraft TW (1998) Rod outer segment maintenance is enhanced in the presence of bFGF, CNTF, and GDNF. Exp Eye Res 66:791-805.

Chang B, Heckinlively JR, Bayley PR, Brecha NC, Davisson MT, Hawes NL, Hirano AA, Hurd RE, Ikeda A, Johnson BA, McCall MA, Morgans CW, Nusinowitz S, Peachey NS, Rice DS, Vessey KA, Gregg RG (2006) The nob2 mouse, a null mutation in Cacnalf: anatomical and functional abnormalities in the outer retina and their consequences on ganglion cell visual responses. Vis Neurosci 23:11-24.

Cuenca N, Pinilla I, Sauve Y, Lund R (2005) Early changes in synaptic connectivity following progressive photoreceptor degeneration in RCS rats. Eur J Neurosci 22:1057-1072.

Delyfer MN, Simonutti M, Neveux N, Léveillard T, Sahel JA (2005) Does GDNF exert its neuroprotective effects on photoreceptors in the rd1 retina through the glial glutamate transporter GLAST? Mol Vis 11:677-687.

Dick O, tom Dieck S, Altrock WD, Ammermüller J, Weiler R, Garner CG, Gundelfinger ED, Brandstätter JH (2003) The presynaptic active zone protein bassoon is essential for photoreceptor ribbon synapse formation in the retina. Neuron 37:775-786.

Dyer MA, Cepko CL (2000) Control of Müller glial cell proliferation and activation following retinal injury. Nat Neurosci 3:873-880.

Enomoto H (2005) Regulation of neural development by glial cell linederived neurotrophic factor family ligands. Anat Sci Int 80:42-52.

Eslamboli A (2005) Assessment of GDNF in primate models of Parkinson's disease: comparison with human studies. Rev Neurosci 16:303-310.

Fjord-Larsen L, Johansen JL, Kusk P, Tornoe J, Gronborg M, Rosenblad C, Wahlber LU (2005) Efficient in vivo protection of nigral dopaminer- 
gic neurons by lentiviral gene transfer of a modified neurturin construct. Exp Neurol 195:49-60.

Frasson M, Picaud S, Leveillard T, Simonutti M, Mohand-Said S, Dreyfus H, Hicks D, Sahel J (1999) Glial cell line-derived neurotrophic factor induces histologic and functional protection of rod photoreceptors in the $r d / r d$ mouse. Invest Ophthalmol Vis Sci 40:2724-2734.

Furuta Y, Lautin O, Hogan BLM, Oliver GC (2000) Retina- and ventral forebrain-specific cre recombinase activity in transgenic mice. Genesis 26:130-132.

Gargini C, Terzibasi E, Mazzoni F, Strettoi E (2007) Retinal organization in the retinal degeneration $10(\operatorname{rd} 10)$ mutant mouse: a morphological and ERG study. J Comp Neurol 500:222-238.

Haeseleer F, Imanishi Y, Maeda T, Possin DE, Maeda A, Lee A, Rieke F, Palczewski K (2004) Essential role of $\mathrm{Ca}^{2+}$-binding protein 4, a $\mathrm{Ca}_{\mathrm{v}} 1.4$ channel regulator, in photoreceptor synaptic function. Nat Neurosci 7:1079-1087.

Hammang JP, Behringer RR, Baetge EE, Palmiter RD, Brinster RL, Messing A (1993) Oncogene expression in retinal horizontal cells of transgenic mice results in a cascade of neurodegeneration. Neuron 10:1197-1209.

Harada C, Harada T, Quah H-MA, Maekawa F, Yoshida K, Ohno S, Wada, Parada LF, Tanaka K (2003) Potential role of glial cell line-derived neurotrophic factor receptors in Müller glial cells during lightinduced retinal degeneration. Neuroscience 122:229-235.

Harada T, Harada C, Kohsaka S, Wada E, Yoshida K, Ohno S, Mamada H, Tanaka K, Parada L, Wada K (2002) Microglia-Muller glia cell interactions control neurotrophic factor production during light-induced retinal degeneration. J Neurosci 22:9228-9236.

Hauck SM, Kinkl N, Deeg CA, Swiatek-de Lange M, Schoffmann S, Ueffling M (2006) GDNF family ligands trigger indirect neuroprotective signaling in retinal glial cells. Mol Cell Biol 26:2746-2757.

He S, Weiler R, Vaney DI (2000) Endogenous dopaminergic regulation of horizontal cell coupling in the mammalian retina. J Comp Neurol 418:33-40.

Heuckeroth RO, Enomoto H, Grider JR, Golden JP, Hanke JA, Jackman A, Molliver DC, Bardgett ME, Snider WD, Johnson Jr EM, Milbrandt J (1999) Gene targeting reveals a critical role for neurturin in the development and maintenance of enteric, sensory, and parasympathetic neurons. Neuron 22:253-263.

Honma Y, Araki T, Gianino S, Bruce A, Heuckeroth R, Johnson E, Milbrandt J (2002) Artemin is a vascular-derived neurotrophic factor for developing sympathetic neurons. Neuron 18:267-282.

Huppe-Gourgues F, Coude G, Lachepelle P, Casanova C (2005) Effects of the intravitreal administration of dopaminergic ligands on the b-wave amplitude of the rabbit electroretinogram. Vision Res 45:137-145.

Jain S, Naughton CK, Yang M, Strickland A, Vij K, Encinas M, Golden J, Gupta A, Heuckeroth R, Johnson Jr EM, Milbrandt J (2004) Mice expressing a dominant negative Ret mutation phenocopy human Hirschsprung disease and delineate a direct role of Ret in spermatogenesis. Development 131:5503-5513.

Jain S, Encinas M, Johnson Jr EM, Milbrandt J (2006a) Critical and distinct roles for key RET tyrosine docking sites in renal development. Genes Dev 20:321-333.

Jain S, Golden JP, Wozniak D, Pehek E, Johnson Jr EM, Milbrandt J (2006b) RET is dispensable for maintenance of midbrain dopaminergic neurons in adult mice. J Neurosci 26:11230-11238.

Jamison JA, Bush RA, Lei B, Sieving PA (2001) Characterization of the rod photoresponse isolated from the dark-adapted primate ERG. Vis Neurosci 18:445-455.

Jing S, Yu Y, Fang M, Hu Z, Holst PL, Boone T, Delaney J, Schultz H, Zhou R, Fox GM (1997) GFR $\alpha-2$ and GFR $\alpha-3$ are two new receptors for ligands of the GDNF family. J Biol Chem 272:33111-33117.

Johnson BA, Ikeda S, Pinto LH, Ikeda A (2006) Reduced synaptic vesicle density and aberrant synaptic localization caused by a splice site mutation in the Rs1h gene. Vis Neurosci 23:887-898.

Jomary C, Thomas M, Grist J, Milbrandt J, Neal MJ, Jones SE (1999) Expression patterns of neurturin and its receptor components in developing and degenerative mouse retina. Invest Ophthalmol Vis Sci 40:568-574.

Jomary C, Darrow RM, Wong P, Organisciak DT, Jones SE (2004) Expression of neurturin, glial cell line-derived neurotrophic factor, and their receptor components in light-induced retinal degeneration. In vest Ophthalmol Vis Sci 45:1240-1246.

Karlsson M, Lindqvist N, Mayordomo R, Hallbook F (2002) Overlapping and specific patterns of GDNF, c-ret and GFR alpha mRNA expression in the developing chick retina. Mech Dev 114:161-165.

Kirik D, Georgievska B, Bjorklund A (2004) Localized striatal delivery of GDNF as a treatment for Parkinson disease. Nat Neurosci 7:105-110.

Koberle PD, Ball AK (2002) Neurturin enhances the survival of axotomized retinal ganglion cells in vivo: combined effects with glial cell line-derived neurotrophic factor and brain-derived neurotrophic factor. Neuroscience 110:555-567.

Kretz A, Jacob AM, Tausch S, Straten G, Isenmann S (2006) Regulation of GDNF and its receptor components GFR- $\alpha 1,-\alpha 2$ and Ret during development and in the mature retino-collicular pathway. Brain Res 1090:1-14.

Ledda F, Paratcha G, Sandoval-Guzmán, Ibáñez CF (2007) GDNF and GFR $\alpha 1$ promote formation of neuronal synapses by ligand-induced cell adhesion. Nat Neurosci 10:293-300.

Liu WG, Lu GQ, Li B, Chen SD (2007) Dopaminergic neuroprotection by neurturin-expressing c17.2 neural stem cells in a rat model of Parkinson's disease. Parkinsonism Relat Disord 13:77-88.

Maeda T, Lem J, Palczewski K, Haeseleer F (2005) A critical role of CaBP4 in the cone synapse. Invest Ophthalmol Vis Sci 46:4320-4327.

Marshak DW (2001) Synaptic inputs to dopaminergic neurons in mammalian retinas. Prog Brain Res 131:83-91.

McBride JL, Kordower JH (2002) Neuroprotection for Parkinson's disease using viral vector-mediated delivery of GDNF. Prog Brain Res 138:421-432.

McDonagh SC, Lee J, Izzo A, Brubaker PL (2007) Role of glial cell-line derived neurotropic factor family receptor $\alpha 2$ in the actions of the glucagon-like peptides on the murine intestine. Am J Physiol Gastrointest Liver Physiol 293:G461-G468.

McGee Saftner L, Abel H, Hauswirth W, Flannery J (2001) Glial cell line-derived neurotrophic factor delays photoreceptor degeneration in a transgenic model of retinitis pigmentosa. Mol Ther 4:622-629.

Meyers EN, Lewandoski M, Martin GR (1998) An Fgf8 mutant allelic series generated by Cre- and Flp-mediated recombination. Nat Genet $18: 136-141$.

Morgan JL, Dhingra A, Vardi N, Wong ROL (2006) Axons and dendrites originate from neuroepithelial-like processes of retinal bipolar cells. Nat Neurosci 9:85-92.

Naughton CK, Jain S, Strickland AM, Gupta A, Milbrandt J (2006) Glial cell line-derived neurotrophic factor-mediated RET signaling regulates spermatogonial stem cell fate. Biol Reprod 74:314-321.

Ogilvie JM, Speck JD, Lett JM (2000) Growth factors in combination, but not individually, rescue $r d$ mouse photoreceptors in organ culture. Exp Neurol 161:676-685.

Oiwa Y, Yoshimura R, Nakai K, Itakura T (2002) Dopaminergic neuroprotection and regeneration by neurturin assessed by using behavioral, biochemical and histochemical measurements in a model of progressive Parkinson's disease. Brain Res 947:271-283.

Peachey NS, Ball SL (2003) Electrophysiological analyses of visual function in mutant mice. Doc Ophthalmol 107:13-36.

Peachey NS, Roveri L, Messing A, McCall MA (1997) Functional consequences of oncogene-induced horizontal cell degeneration in the retinas of transgenic mice. Vis Neurosci 14:627-632.

Peichl L, Gonzalez-Soriano J (1993) Unexpected presence of neurofilaments in axon-bearing horizontal cells of the mammalian retina. J Neurosci 13:4091-4100.

Peichl L, Gonzalez-Soriano J (1994) Morphological types of horizontal cell in rodent retinae: a comparison of rat, mouse, gerbil, and guinea pig. Vis Neurosci 11:555-557.

Politi L, Rotstein N, Carri N (2001) Effect of GDNF on neuroblast proliferation and photoreceptor survival: additive protection with docosahexaenoic acid. Invest Ophthalmol Vis Sci 42:3008-3015.

Pozas E, Ibáñez C (2005) GDNF and GFR $\alpha 1$ promote differentiation and tangential migration of cortical GABAergic neurons. Neuron 45:701-713.

Rhee KD, Ruiz A, Duncan JL, Hauswirth WW, LaVail MM, Bok D, Yang X-J (2007) Molecular and cellular alterations induced by sustained expression of ciliary neurotrophic factor in a mouse model of retinitis pigmentosa. Invest Ophthalmol Vis Sci 48:1389-1400. 
Rothermel A, Layer PG (2003) GDNF regulates chicken rod photoreceptor development and survival in reaggregated histotypic retinal spheres. Invest Ophthalmol Vis Sci 44:2221-2228.

Rothermel A, Volpert K, Schlichting R, Huhn J, Stotz-Reimers M, Robitzki AA, Layer PG (2004) Spatial and temporal expression patters of GDNF family receptor $\alpha 4$ in the developing chicken retina. Gen Expr Patterns 4:59-63.

Sah DW, Ossipov MH, Rossomando A, Silvian L, Porreca F (2005) New approaches for the treatment of pain: the GDNF family of neurotrophic growth factors. Curr Top Med Chem 5:577-583.

Sariola H, Saarma M (2003) Novel functions and signaling pathways for GDNF. J Cell Sci 116:3855-3862.

Schuchardt A, D’Agai V, Larsson-Blomberg L, Costantini F, Pachnis V
(1994) Defects in the kidney and enteric nervous system of mice lacking the tyrosine kinase receptor Ret. Nature 367:380-383.

Sharma RK, O'Leary TE, Fields CM, Johnson DA (2003) Development of the outer retina in the mouse. Dev Brain Res 145:93-105.

Uesaka T, Jain S, Yonemura S, Uchiyama Y, Milbrandt J, Enomoto H (2007) Conditional ablation of GFR $\alpha 1$ in postmigratory enteric neurons triggers unconventional neuronal death in the colon and causes a Hirschsprung's disease phenotype. Development 134:2171-2181.

Zhu Y, Zhang Y, Ojwang BA, Brantley Jr MA, Gidday JM (2007) Longterm tolerance to retina ischemia by repetitive hypoxic preconditioning: role of HIF- $1 \alpha$ and heme oxygenase-1. Invest Ophthalmol Vis Sci 48:1735-1743. 